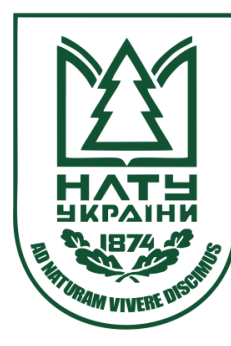

Науковий вісник НлтУ України Scientific Bulletin of UNFU

ISSN 1994-7836 (print)

http://nv.nltu.edu.ua

https://doi.org/10.15421/40280424

Article received 02.03.2018 p.

Article accepted 26.04.2018 p.

N. M. Yurkiv

удК 631.15:658.27

borysnadia@ukr.net

Н. М. Юрків

Національний лісотехнічний університет Украйни, м. Львів, Украйна

\title{
ПОБУДОВА МОДЕЛІ ПРОЦЕСУ ФОРМУВАННЯ СТРАТЕГІЙ ЕКОЛОГО-БЕЗПЕЧНОЇ ЕКСПОРТНОЇ ДІЯЛЬНОСТІ ЛІСОГОСПОДАРСЬКИХ ПІДПРИЄМСТВ
}

Оцінюючи значення, роль та місце стратегій еколого-безпечної експортної діяльності лісогосподарських підприємств у ієрархії стратегічного набору лісогосподарського підприємства, встановлено, що для лісогосподарського підприємства "портфель стратегій еколого-безпечної експортної діяльності підприємства" повинен містити сукупність стратегій, що визначаються для кожного екологічного об'єкта відповідно до рівня його екологічного потенціалу, мати спільну мету і бути взаємозалежними за часом та кількістю вилучених і компенсованих екологічних ресурсів. Обгрунтовано, що стратегії еколого-безпечної діяльності повинні розроблятися з урахуванням вимог продуктових, ресурсних і функціональних стратегій, тобто забезпечити їх реалізацію на екологічно безпечному рівні. Встановлено основні концептуальні підходи, послідовність і зміст процесу формування стратегій еколого-безпечної експортної діяльності лісогосподарського підприємства. Окреслено основні етапи та побудовано концептуальну модель процесу формування стратегій еколого-безпечної експортної діяльності лісогосподарських підприємств, яка відповідає вимогам сталого природокористування та адаптована до змін зовнішнього середовища. З'ясовано, що стратегічне планування діяльності лісогосподарського підприємства матиме успіх тільки за умови наявності у керівництва підприємства методичного апарату щодо оцінювання ефективності реалізації еколого-безпечних стратегій.

Ключові слова: еколого-безпечні стратегії; експортна діяльність лісогосподарського підприємства; стратегічний "портфель" підприємства; концептуальна модель.

Вступ. Концепція сталого природокористування грунтується на тому, що в сучасних умовах людина здатна запобігти, або, в крайньому випадку, локалізувати і зменшити рівень загрози несприятливих економічних ситуацій, що можуть бути результатом експлуатаційного навантаження на природні ресурси. Це можна досягнути за допомогою розроблення та реалізації лісогосподарськими підприємствами, що своєю діяльністю істотно впливають на природне середовище, дієвих еколого-безпечних стратегій своєї діяльності (Koval, 2012; Fishuk et al., 2012).

Враховуючи те, що матеріальне навантаження на природні ресурси, зокрема, заготівля деревини для експорту на території певного підприємства, зумовлює значний, а часто тривалий резонанс навколишнього середовища, а сучасне швидкоплинне зовнішнє середовище, цим самим впливає на діяльність підприємства, потрібно активно впроваджувати стратегічні підходи до управління еколого-безпечною експортною діяльністю. Ці підходи даватимуть лісогосподарському підприємству оперативно й адекватно реагувати на зміни зовнішнього середовища, і насамперед забезпечувати екологічно безпечний рівень процесу матеріального навантаження на лісові ресурси.

Істотні корективи в експортну діяльність підприємства можуть вносити такі чинники зовнішнього середовища: стан зовнішнього ринку деревини, зміни норма- тивних екологічних вимог на рівні держави чи регіону, економічна i, навіть, політична ситуація в державі (Melnyk et al., 2013).

Тому в стратегічному управлінні експортною діяльністю лісових підприємств важливого значення набуває методично обгрунтоване формування стратегій своєї еколого-безпечної діяльності, а також наявності критеріїв для оцінювання ефективності їх реалізації.

Матеріали та методи дослідження. За визначенням вітчизняних і зарубіжних вчених, екологічна стратегія (зокрема, й експортної діяльності) - це довготермінові цілі та задачі підприємства, спрямовані на ліквідацію руйнувань чи компенсацію порушень природного середовища, що стали наслідками певної господарської діяльності підприємства (Gavrylenko, 1996; Doval, 2016; Shaikh, 2010). Окремі дослідники розглядали стратегію як перелік правил для прийняття рішень, якими організація повинна користуватися у своїй діяльності (Ansoff, 1989).

Для багатопрофільних підприємств загальною стратегією є об'єднання і взаємоузгодження системи стратегічних зон господарювання, що визначається "портфелем підприємства" з власними методами управління, недоліками та перевагами (Gonchrov, 1993). Зважаючи на певні особливості, для окремого лісогосподарського підприємства "портфель стратегій еколого-безпечної експортної діяльності підприємства" є сукупністю стра-

\section{Інформація про авторів:}

Юрків Надія Миколаївна, аспірант. Email: borysnadia@ukr.net

Цитування за Дсту: Юрків Н. М. Побудова моделі процесу формування стратегій еколого-безпечної експортної діяльності лісогосподарських підприємств. Науковий вісник НЛтУ України. Серія Економічна. 2018, т. 28, № 4. С. $128-131$

Citation APA: Yurkiv, N. M. (2018). Construction of the Model of the Strategies Formation of the Environmemtally Friendly Export Activity of Forestry Enterprises. Scientific Bulletin of UNFU, 28(4), 128-131. https://doi.org/10.15421/40280424 
тегій еколого-безпечної експортної діяльності, що визначаються для кожного екологічного об'єкта відповідно до рівня його екологічного потенціалу, мають спільну мету і взаємозалежні за часом та кількістю вилучених і компенсованих екологічних ресурсів.

Тому невідкладним завданням наукових досліджень щодо методики розроблення стратегій еколого-безпечної експортної діяльності (екологічних стратегій), на думку автора, є встановлення етапів формування стратегій та узгодженості між ними з урахуванням чинників, що на них впливають.

Метою дослідження $\epsilon$ обгрунтування та побудова концептуальної моделі процесу формування стратегій еколого-безпечної експортної діяльності лісогосподарських підприємств відповідно до умов сталого природокористування.

Результати дослідження. Головною метою будьякого підприємства $є$ його розвиток і зростання. Однак у реальному житті досить часто виникають умови, за яких намічені перспективи розвитку, зокрема, експортного виробництва, ускладнюються встановленими екологічними вимогами. Саме наявність таких умов є характерною для лісових підприємств Львівської обл.

Маючи значний власний ресурсний потенціал, а також значний рівень попиту на лісопродукцію на міжнародному ринку, більшість лісогосподарських підприємств Львівщини здійснюють свою виробничу діяльність в умовах жорстких екологічних норм і вимог. Організувати належним чином експортне виробництво сприяють саме стратегії еколого-безпечної експортної діяльності.

Головною метою таких стратегій є створення балансу між матеріальним навантаженням на природні ресурси і фінансовими, технологічними та управлінськими можливостями підприємства щодо компенсації природі вилучених ресурсів. Вимоги щодо еколого-безпечної експортної діяльності реалізуються через стратегії екологічної безпеки для кожного із екологічних об'єктів, які залучені в цей процес. Такі стратегії потрібно розробляти з урахуванням вимог продуктових, ресурсних $\mathrm{i}$ функціональних стратегій для забезпечення їх реалізації на екологічно безпечному рівні.

Якщо розглядати еколого-безпечні стратегії експортної діяльності як сукупність заходів, що оптимізують вхідні та вихідні потоки екологічних ресурсів об'єкта залежно від стану цих об'єктів (екологічного потенціалу об'єкта), то для встановлення щільності взаємодії цих стратегій на об'єкти підприємства потрібно визначитися 3 тим, якою мірою вихідні потоки з одного об'єкта можуть бути компенсовані вхідними потоками (ресурсами на відновлення) іншого екологічного об'єкта.

Проведені дослідження (Borys, 2013; Yurkiv, 2015) дають змогу визначитися 3 концептуальними підходами, послідовністю і змістом процесу розроблення стратегій еколого-безпечної експортної діяльності лісогосподарського підприємства, модель якого подано на рисунок.

Наведена концептуальна модель цього процесу грунтується на тому, що стратегічна мета визначається за умов чітких концептуальних положень щодо управління еколого-безпечними процесами, а саме:
- стале природокористування - забезпечення збереження (відновлення) первозданного екологічного стану природних територій підприємства для майбутніх поколінь;

- актуалізація стратегічних підходів - адаптація стратегій еколого-безпечної експортної діяльності до змін зовнішнього середовища (економічної ситуації на міжнародному ринку лісопродукції, екологічних норм і вимог на регіональному і державному рівнях, екологічного стану природних територій інших лісогосподарських підприємств регіону, напрямів розвитку суміжних галузей народного господарства).



Рисунок. Концептуальна модель процесу розроблення стратегій еколого-безпечної експортної діяльності (авторська розробка)

Запропонована модель процесу розроблення стратегій еколого-безпечної експортної діяльності лісогосподарського підприємства передбачає такі етапи.

Перший етап прочесу. Екологічні аспекти стратегічного управління визначають те, що експлуатація природних ресурсів для виробництва експортної продукції $\epsilon$ можливою тільки в тому випадку, коли на території підприємства $\epsilon$ екологічні об'єкти 3 необхідним екологічним потенціалом експортного виробництва.

Другий етап процесу. Визначення можливих напрямів еколого-безпечного експортного виробництва (еколого-безпечних стратегій) для кожного екологічного об'єкта, що задіяний у процесі експортного виробництва, забезпечує стратегічний аналіз матриці екологічних потенціалів. 
Tретій етап процесу. Процес розроблення екологобезпечної стратегії для кожного з екологічних об'єктів повинен обов'язково передбачати етап узгодження цих стратегій з ресурсними, продуктово-товарними і функціональними стратегіями підприємства.

Четвертий етап процесу. За наявності необхідного консенсусу між складовими стратегічного набору підприємства можлива реалізація етапу оптимізації "портфеля екологічних стратегій еколого-безпечної експортної діяльності екологічних об'єктів підприємства". Результатом оптимізації "портфеля" є загальна стратегія еколого-безпечної експортної діяльності підприємства.

П'ятий етап процесу. Практична реалізація такої стратегії можлива тільки за умов узгодження іiі із загальною стратегією розвитку підприємства.

Шостий етап прочесу. Проведений аналіз дає змогу керівництву підприємства оцінити стратегічний набір свого підприємства і визначитися зі змістом та послідовністю роботи щодо розроблення еколого-безпечних стратегій для відповідних видів економічної діяльності.

Однак, варто розуміти, що визначення еколого-безпечних стратегій $є$ не одноразовим актом, а постійною напруженою роботою щодо розроблення стратегічних альтернатив еколого-безпечної діяльності підприємства 3 урахуванням змін зовнішнього середовища.

Висновок. Отже, процес розроблення стратегій еколого-безпечної експортної діяльності повинен складатися із низки взаємопов'язаних та взаємодоповнювальних етапів, які сукупно повинні дати такий "портфель" стратегій лісогосподарського підприємства, які відповідали б вимогам сталого природокористування та були адаптовані до змін природного середовища.

Успіх стратегічного планування еколого-безпечної діяльності лісогосподарського підприємства значною мірою визначається наявністю у керівного складу методичного апарату для оцінювання ефективності реалізації еколого-безпечних стратегій.

\section{Перелік використаних джерел}

Ansoff, I. (1989). Strategicheskoe upravlenie. [Strategic management]. Moscow: Economy. [In Russian].

Borys, N. M. (2013). Upravlinnia ekologichnoy bezpekoy exportnoi dialnosti pidpryemstv lisovogo gospodarstva za umov stalogo lisokorystuvania. [Ecological safety management of export activity of forest enterprises under conditions of sustainable forest management]. Scientific Bulletin of UNFU, 23(17), 101-107.

Doval, E. (2016). Some issues regarding companies' international environment strategic analyses as the change management process first step. Cconvergent discourses. Exploring the Contexts of Communication Arhipelag XXI Press, Tîrgu Mureş, Section: Social Sciences, 130-140. Retrieved from: http://www.upm.ro/cci/CCI04/Soc/Soc\%2004 \%2014.pdf

Fishuk, N. Yu., \& Berezuk, Yu. B. (2012). Strategia formuvania ta rozvytku exportnogo potencialu agroprodovolchogo sektora ekonomiky. [Strategy for the formation and development of export potential of the agro-food sector of the economy]. Zbirnyk naukovyh prats VNAU, 3(69), 218-226. [In Ukrainian].

Gavrylenko, N. M. (1996). Geograficheskie problem strategii ustoichevogo rozvitia prirodnoi sredy e obchestva. [Geographical problems of the strategy of sustainable development of the natural environment and society]. Moscow: Geographia. [In Russian].

Gonchrov, V. (1993). V poiskah soverchenstva upravlenia: Rukovodstvo dla vyschego ypravlencheskogo personala. [In Search of Excellence Management: A Handbook for Senior Management Personnel]. Moscow: MP "Suvenir". [In Russian].

Koval, Ya. (2012). Priorytety ekologichnogo ta zbalansovanogo lisoresursnogo rozvytku. [Priorities of ecological and balanced forest resource development]. Ekonomist, 12, 49-51. [In Ukrainian].

Melnyk, O. G., \& Nagirna, M. Ya. (2013). Diagnostyka faktoriv vplyvu na exportnu dialnist pidpryenstva. [Diagnostics of the factors of floating on export activity]. Innovational economy, 5, 63-66. [In Ukrainian].

Shaikh, S. (2010). Business environment. New Delhi: Pearson.

Yurkiv, N. M. (2015). Ekologo-ekonomichni zasadu formuvania strategichnogo naboru lisovyh pidpryenstv. [Ecological and economic formation principles of a strategic set of forest enterprises]. Zbalansovane prurodokorystuvania, 1, 28-31.

\section{ПОСТРОЕНИЕ МОДЕЛИ ПРОЦЕССА ФОРМИРОВАНИЯ СТРАТЕГИЙ ЭКОЛОГО-БЕЗОПАСНОЙ}

ЭКСПОРТНОЙ ДЕЯТЕЛЬНОСТИ ЛЕСОХОЗЯЙСТВЕННЫХ ПРЕДПРИЯТИЙ

Оценивая значение, роль и место стратегий эколого-безопасной экспортной деятельности лесохозяйственных предпри-
ятий в иерархии стратегического набора лесохозяйственного предприятия, установлено, что для лесохозяйственного пред-
приятия "портфель стратегий эколого-безопасной экспортной деятельности предприятия" должен содержать совокупность
стратегий, определяющихся для каждого экологического объекта в соответствии с уровнем его экологического потенциала,
иметь общую цель и быть взаимозависимыми по времени и количеству изъятых и компенсированных экологических ресур-
сов. Обосновано, что стратегии эколого-безопасной деятельности должны разрабатываться с учетом требований продукто-
вых, ресурсных и функциональных стратегий, то есть обеспечить их реализацию на экологически безопасном уровне. Уста-
новлены основные концептуальные подходы, последовательность и содержание процесса формирования стратегий эколого-
безопасной экспортной деятельности лесохозяйственного предприятия. Определены основные этапы и построена концепту-
альная модель процесса формирования стратегий эколого-безопасной экспортной деятельности лесохозяйственных пред-
приятий, которая отвечает требованиям устойчивого природопользования и адаптирована к изменениям внешней среды.
Выяснено, что стратегическое планирование деятельности лесохозяйственного предприятия будет иметь успех только при
условии наличия у руководства предприятия методического аппарата в оценке эффективности реализации эколого-безопас-
ных стратегий.
Ключевые слова: эколого-безопасные стратегии; экспортная деятельность лесохозяйственного предприятия; стратегический "портфель" предприятия; концептуальная модель.

N. M. Yurkiv

Ukrainian National Forestry University, Lviv, Ukraine

\section{CONSTRUCTION OF THE MODEL OF THE STRATEGIES FORMATION OF THE ENVIRONMEMTALLY FRIENDLY EXPORT ACTIVITY OF FORESTRY ENTERPRISES}

Assessing the importance, role and place of the strategies of environmentally friendly export activities of forest enterprises in the hierarchy of the strategic set of forest enterprises, the authors have revealed that for the forest enterprise strategies portfolio of environmentally friendly export activity of the enterprise should contain a set of strategies that are determined for each environmental ob- 
ject according to the level of its environmental potential, should have a common goal and should be interrelated in time and number of seized and compensated ecological resources. It is substantiated that environmentally friendly activity strategies should be elaborated according to the requirements of products, resources and functional strategies, namely, to ensure their implementation at an environmentally safe level. These approaches will allow the forestry enterprise to react promptly and adequately to changes in the environment, and, first of all, to ensure an environmentally safe level of material load on forest resources. The basic conceptual approaches, sequence and content of the process of strategies formation of ecologically safe export activity of the forest enterprise are defined. The main stages are outlined and the conceptual model of the process of formation of strategies for environmentally friendly export activities of forest enterprises, which is comply with the sustainable nature management requirements and adapted to changes in the environment, are constructed. Defining environmentally friendly strategies is not a one-time act, but a constant tense work on developing strategic alternatives to the environmentally safe activity of the enterprise, according to the environment changes. It is revealed that strategic planning of the forestry enterprise activity will succeed only if the management of the enterprise has a methodological apparatus for assessing the effectiveness of implementing environmentally safe strategies.

Keywords: environmentally friendly strategies; export activity of a forestry enterprise; strategic portfolio of the enterprise; conceptual model. 